\title{
Electronic Procurement and Cost Saving in the Fast Moving Consumer Goods: A Case Study of Retail Sector in Zimbabwe
}

\author{
Mike Nyamazana Sikwila \\ Chinhoyi University of Technology, School of Business Sciences and Management, \\ P Bag 7724, Chinhoyi, Zimbabwe \\ Email: msikwila01@gmail.com; mikesikwila@yohoo.com
}

\section{Godwell Karedza}

School of Business Sciences and Management, Chinhoyi University of Technology, Chinhoyi, Zimbabwe

\section{Doi:10.5901/mjss.2016.v7n4p}

\section{Abstract}

In this paper, the authors explored the use of e-procurement in Zimbabwe's fast moving consumer goods industry. There are several studies that have been done in developed economies regarding e-procurement in retail sector. However, the literature was scanty on issues of e-procurement cost saving in the fast moving consumer goods industry in developing countries. It is against this background, that we sought to close the gap in the literature on the use of internet in Zimbabwe's fast moving consumer goods industry. We utilized an economic order quantity (EOQ) theoretical framework to demonstrate that an adoption of e-procurement could save cost in Zimbabwe's fast moving consumer goods industry. We carried out a survey of firms in the fast moving consumer industries in Zimbabwe. A cross-sectional study design was employed to collect data from 56 respondents from DCK, OK Zimbabwe and Spar retailers, chosen using simple probability sampling method in the course of January 2014 to March 2015. We examined e-procurement operations of these retailers located in selected major towns of Zimbabwe. The hypothesis tested was that e-procurement does not exist in Zimbabwe's retail sector. The results indicate little e-procurement use in Zimbabwe's retail fast moving consumer sector. It was expected that these results should shed light to policy makers in the private sector and government and thereby encourage them to embark on policies that enhance eprocurement in the fast moving consumer goods industries. Subsequently, we conclude that the adoption of e-procurement should lower administrative ordering cost and thereby improving the profit margins of firms in the retail sector.

Keywords: E-procurement, retail, electronic, business, strategy, tourism and hospitality sector

\section{Introduction}

Procurement is the purchase of goods and services by one business entity from another. This could be done through various ways depending on the company's procurement process system. We define electronic procurement (eprocurement) as purchase and/or ordering of goods and services by companies through the use of internet. Thus, eprocurement could be done through business-to-business, business-to-consumer and business-to-government. Eprocurement has revolutionized the way business is done throughout the world (Lenung \& Law, 2013). Studies on adoption of e-procurement in developed economies include: Essig \& Arnold, 2006; Grandon \& Peeason, 2004; Laryea \& Ibem, 2014 and Lenung \& Law, 2013. However, these studies have not explored the adoption of e-procurement in Zimbabwe or addressed the population of enterprises in Less Developing Countries. In an attempt to address the deficiency of these previous studies we examined whether Zimbabwe's fast moving consumer goods sector have adopted e-procurement in their effort to reduce administrative ordering cost and improve competitiveness of their operations. In line with this, the study also reviews inhibitors and benefits towards e-procurement adoption. The research also sought to raise the general level of awareness of e-procurement and its capabilities among retailers and highlight ways of promoting growth of the phenomenon in Zimbabwe.

Following an observation on the use of e-procurement by DCK, OK Zimbabwe and Spar were selected for this study in that they constitute 95\% of Zimbabwe's retail industry. Spar represents one of the fastest growing foreign franchises in the country. OK Zimbabwe is a public listed company, and is one of Zimbabwe's traditional and long established retail chains; also it has activities in South Africa. DCK supermarket, which has a significant number of retail 
outlets represent indigenous or local operators owned franchises.

The e-procurement often takes the form of business-to-business (B2B), business-to-consumer (B2C), and business-to-government (B2G) among others (Alor-Hernandez, Aguilar-Laserre, Cortes-Robles, \& Sanchez-Ramirez, 2011). However, the adoption and growth of the E-procurement in Zimbabwe is slow to take root and this was particularly so among consumer retail in the fast moving consumer goods sector. The problem was that purchasing in Zimbabwe is still by and large a paper world. It takes weeks to get a purchase approved through the manual re-occurring process at the supplier end which takes place before a despatch is done, followed by the paper chase called accounts payable. An adoption of automation and introduction of e-procurement could lead to better requisition and approval process, approval time and effort. The e-procurement could assist suppliers to receive orders directly into their sales order processing system without delay.

The purpose of the study is to explore the use of e-procurement in Zimbabwe. The problem is that most firms face high ordering (administrative) cost, perhaps, due to inability to adopt cost cutting strategies such as e-procurement. The objectives of the study were to: establish the degree of e-procurement adoption and usage in the fast moving consumer goods sector in the country, highlight benefits of e-procurement for business, and identify constrains to e-procurement growth in Zimbabwe.

The question that has not been answered is why the businesses in Zimbabwe have not embraced e-procurement at the same rate as other countries in the developed world in view of the fast growing globalization? The research seeks to resolve this question based on the empirical evidence collected from three retail chains (with several branches throughout the country). We argue that currently there are no major developments in e-procurement implementation in Zimbabwe, across all the sectors. The importance of this study is to enhance the effectiveness of supply chain management in organisations. Also, this study is important in that it sheds light to industries such as those within the hospitality and tourism sector with empirical evidence on organisational readiness and current levels of utilisation of eprocurement. Furthermore, the study identifies key benefits and constrains to e-procurement adoption. The research will also pinpoint key factors needed to promote e-procurement use. Findings of this research will help policy makers at company and national level to come up with appropriate polices and measures to boost growth of e-procurement in Zimbabwe. The study is therefore necessary in that it will fill in existing information gaps regarding e-procurement and answer questions as to why the industry has not been enthusiastic about the phenomenon. With the general recognition of the role of e-procurement in overcoming national geographical and temporal boundaries to intra-trade, companies that aspire to cut costs cannot afford to ignore e-procurement (Essig \& Arnold, 2006; Grandon \& Peeason, 2004).

An economic order quantity (EOQ) theoretical framework has been employed to explain the ordering cost saving aspects resulting in the adoption of e-procurement in Zimbabwe's fast moving consumer industry.

A cross-sectional study design was employed to collect data from the 56 respondents of top managers, middle managers and technical staff chosen using a simple random sampling method. The location included all towns in Zimbabwe where DCK, OK Zimbabwe and Spar had subsidiaries. The SPSS version 21 computer package was used to analyse the data collected from the three fast moving consumer retail markets. The results indicate that there was insignificant use of e-procurement in Zimbabwe's fast moving consumer goods industry. We aver that implementation of e-procurement enhances competitive advantage. It is against this context that this study contributes in persuading Zimbabwe's fast consumer goods industry and those in other Less Developing Countries (LDC) to adopt a cost cutting ordering and/or administrative cost embedded in the use of electronic procurement, and thereby improving the profit margins of firms in the retail sector. To establish to what extent the e-procurement is used in the fast moving consumer goods in Zimbabwe we adopted the following hypotheses:

Hypotheses: The null hypothesis $\left(\mathrm{H}_{0}\right)$ : electronic procurement does not exist in the fast moving consumer goods retail sector in Zimbabwe $\mathrm{H}_{0}: \boldsymbol{\beta}=\mathbf{0}$. The Alternative Hypothesis $\left(\mathrm{H}_{1}\right)$ : electronic procurement exists in the fast moving consumer goods retail sector in Zimbabwe $\mathbf{H}_{1}: \boldsymbol{\beta} \neq \mathbf{0}$. In summary, the results showed that e-procurement is scant in Zimbabwe's retail industries. The results also indicate that e-procurement was insignificant in terms of its use in the B2B transactions and none at all in B2C and B2G sectors.

The study is divided into five sections: Section One gives the introduction and briefly explains the purpose, problem and objectives of the study, Section Two give the literature review of e-procurement. Section Three, presents the methodology and results, Section Four presents the discussion. Finally Section Five gives the conclusion.

\section{Literature Review}

In this section we reviewed selected studies on the adoption of e-procurement. E-business encompasses all the activities that the fast moving consumer goods sector (FMCG) performs in selling and buying products and services using 
computers and communication technologies (Bidgoli, 2013). In a study of e-procurement in Singapore, Teo, Lin and lai (2009) explain that e-procurement was positively influenced by firm size, top management support, perceived indirect benefits and business partner influence. In particular, this was apparent in large firms that had large volume of transactions. Large firms possessed resources that allowed them to adopt e-commerce (Chen, 2011; Bidgoli, 2013) focusing on electronic purchasing (Teo, Lin \& Lai, 2009). Mcmanus (2002) explains that the lower cost of transactions for both sellers and buyers could be an attractive factor for implementation of e-procumbent by organization. The low cost factor is also supported by Subramanium and Shaw (2002) who avers that e-commerce improves organizational interdependence and information sharing. Thus, businesses-to-business (B2B) transaction cost are lowered by the introduction of e-procurement in an organization. Bidgoli (2013) contends that e-commerce creates "price transparency" meaning that all market participants can trade at the same price. Subsequently, this could lead to adoption of eprocurement by firms that have not yet adopted the electronic procurement (Subramanium \& Shaw, 2002). Whilst electronic data interchange (EDI) and electronic funds transfer (EFT) have been around for many years, in recent years, the Internet has increased the number of B2B transactions and made B2B the fastest growing segment of e-commerce (Brevis \& Vrba, 2014; Bidgoli, 2013) resulting in B2B procurement positively impacting on inter-organizational electronic linkages making it easy to source various products on the market by businesses. The shift by organizations and consumers from using paper work such as invoices and catalogues to electronic procurement has reduced the purchasing time for B2B, business-to-consumer (B2C) business-to-government (B2G), and thereby leading to the use of the spare time for other economic activities (Rajkumar, 2001; MacManus, 2002). A most important variable for less developing countries to adopt and implement e-procurement is the perception of the consumers and trust of the organizations. To successfully implement e-procurement an organization has to possess good-will and relatively good governance in order to sustain models such as B2B, B2C C2C and B2G transaction activities (de Boer, Harink, \& Heiboer, 2002; Croom \& Johnson, 2003).

Bidgoli (2013) motivates that Seller-Side Marketplace model has e-procurement application which enables employees in the fast moving consumer goods sector (FMCG) to order and receive supplies and services directly from suppliers, invariably proffering the company negotiated reduced prices with suppliers ahead of time. Brevis and Vrba (2014) indicate that e-procurement offers a breakthrough improvement in the supply chain. Further, Bidgoli (2013) argues that e-procurement streamlines the traditional procurement process which reduces costs, saves time and improves relationships between suppliers and participating organisations. Brevis and Vrba (2014) argue that e-commerce and its capabilities, offers a competitive advantage relationship between management information systems and levels of management in relation to supply chain (Smit, Cronje, Brevis and Vrba, 2011). To that effect, Bidgoli (2013) asserts that the main objectives of e-procurement are to prevent purchases from suppliers that are not on the approved list of sellers and eliminate the processing costs of purchases.

Governments have not been keen to adopt e-procurement (MacManus, 2002) and this is particularly the case for governments in the Sub-Saharan countries. The private firms in this part of the world have not pursued e-procurement with similar emphasise as firms in the developed world. Perhaps the lack of leadership in e-procurement by the private sector has not enticed governments to adopt e-procurement (MacManus, 2003:21). MacManus (2003) explains that governments have stuck to the traditional procurement principles of "low bid wins; separation between the vendor and user; fixed price and fixed term contracts and open access" (MacManus, 2002). If private sector could show by use of eprocurement that it supersedes "traditional principles" of procurement, perhaps governments would be persuaded to adopt e-procurement. E-procurement has further added value in reduction of order cycles and time to market by using online purchasing (Grandon \& Pearson, 2004).

Batenburg (2007) found that there were differences in the adoption of e-procurement in seven European countries, depending on how firms in a particular country viewed the value of e-procurement adoption. In a similar study to that of Batenburg (2007), Leung \& Law (2013) found that the adoption of electronic data interchange and e-procurement in hospitality industries that includes hotels was low in Hong Kong. Similarly, Pycraft, Singh, Phihlela, Slack, Chambers, and Johnston (2013) argue that not everyone is happy with e-procurement as some see it as preventing the development of closer partnership-type of relationships, which in the long run, could bring far greater returns. Pasiopoubs et al., (2013) in a study of Greece public hospitals regarding the perception of workers on e-procurement use, found that the employees were willing to embrace e-procurement. In this light it was possible to adopt e-procurement in Greece public hospitals in that employees were ready to learn and benefit from the value of information technology (Pasiopoubs, et. al., 2013). Laryea and Ibem (2014) carried out a study of web-based e-procurement in the construction industry in which they reviewed literature on construction uptake and application of e-procurement between 1978 and 2013, and found that there was a substantial use of e-procurement in the construction industry worldwide. 


\section{Methodology and Results}

Economic order-Quantity Model (EOQ): We make use of economic order quantity concept, which is the trade-off between ordering cost and storage cost used by fast-moving consumer goods firms in ascertaining the build-up or replenishment in their inventory (Leopoldo Eduardo Cardenas-Barron, et al., 2014; Liang-Yuh Ouyanga, et al., 2013; Sheng-Chih Chen ${ }^{a}$, et al., 2014; Pattnaik, 2013; Jafar Rezaeia ${ }^{\text {, }}$ et al., 2012; Mehmood Khan ${ }^{\mathrm{a}}$, et al, 2011; Bacel Maddah', et al., 2008 and Yung-Fu Huang, 2007). Larger order-quantity of inventory leads to lower frequency in ordering inventory, subsequently lowering the cost of ordering in form of logistic, transport costs and packaging. On the other hand, small orders increase the ordering costs. However, the decision of the appropriate order quantity should be done in a way that facilitate trade-offs between these costs and storage cost. But in fast moving consumer goods industry storage costs are assumed to be low. Hence, the firms are expected to choose cost-minimizing order-quantity that will necessarily lead to appropriate ordering frequency. The use of minimum order-quantity or economic order quantity is beneficial for the fastmoving consumer goods companies. Subsequently, the model is useful for management decision in the fast-moving consumer goods industries. However, in this paper we assert that the adoption of the electronic procurement (eprocurement) was expected to lower the main costs such as logistic, transport cost and paper work currently used in Zimbabwe's fast moving consumer goods industries.

In an attempt to show how administrative cost is reduced by adoption of e-procurement an economic order quantity (EOQ) theoretical framework is utilized. An economic order quantity business scenario assumes that managers select a quantity $\mathrm{Q}$ that minimizes the average inventory management cost per unit time, be it annual, monthly or weekly in units of currency used. The average cost $A C(Q)$ can be presented as:

$\mathrm{AC}(\mathrm{Q})=\phi^{*}(\Omega / \mathrm{Q})+\psi *(\mathrm{Q} / 2)+\hat{\mathrm{C}} * \Omega$

In equation (1) AC is the average cost and Q quantity. $\Phi$ is fixed order cost, * is multiplication sign, $\Omega$ is consumer demand for the product to be sold ${ }^{1}$ assumed to be constant over time, $\psi$ is inventory holding cost rate; and $\hat{C}$ is the unit cost of a product to be sold. Also, in equation (1) the first term represents the average monthly ordering cost in that we assume that in the fast consumer goods industries ordering is done on monthly basis and lead time is zero implying immediate delivery whenever orders are placed. The second term, in equation (1) represents the holding cost, which depends on space and all risks involved in holding a product. The third term is the average unit cost.

However, the third term $\hat{\mathrm{C}}{ }^{*} \Omega$ is not involved in determining average cost from $\mathrm{Q}$ which we can omit in equation (2) presented as;

$\mathrm{AC}(\mathrm{Q})=\Phi^{*}(\Omega / \mathrm{Q})+\psi^{*}(\mathrm{Q} / 2)$

Thus equation (2) implies that average ordering cost decreases as $\mathrm{Q}$ increases and that as $\mathrm{Q}$ increases average holding cost increases. In which case minimum $\mathrm{AC}(\mathrm{Q})$ is achieved when average ordering cost equal average holding cost per month given as;

$\Phi^{*}\left(\Omega / \mathrm{Q}^{\circ}\right)=\psi^{*}\left(\mathrm{Q}^{\circ} / 2\right)$ obtain;

In equation (3) $\mathrm{Q}^{0}$ is the economic order quantity or optimal $\mathrm{Q}$. Making $\mathrm{AC}\left(\mathrm{Q}^{\circ}\right)$ the subject in equation (3) we

$$
\mathrm{AC}(\mathrm{Qo})=\sqrt{2 * \Phi * \Omega * \psi}
$$

Thus, average monthly cost is given by the square root of the product of $2, \Phi$; administrative cost, $\Omega$ the consumer demand for the product and $\psi$, the holding cost. The total cost per month is given as;

$$
\mathrm{TC}(\mathrm{Qo})=\sqrt{2 * \Phi * \Omega * \psi}+\hat{\mathrm{C}} * \Omega
$$

In equation (5) we add to equation (4) the average unit cost to obtain the total cost $\mathrm{TC}\left(\mathrm{Q}^{\circ}\right)$ function.

The adoption of e-procurement is assumed to lead to a reduction in the ordering cost (administrative cost) $\Phi$ which involves paper work prevalent in Zimbabwe's firms. An adoption of e-procurement was expected to reduce administrative cost involved with ordering cost and logistic and thereby improve on the profit margins of fast-moving consumer goods industries in Zimbabwe and other developing countries. To determine whether the fast moving consumer firms use eprocurement, a survey was conducted in the course of January 2014 to March 2015 in Zimbabwe's retail industries.

The population consisted of the fast moving consumer goods enterprises in OK Zimbabwe, Spar, and DCK super markets located in selected major towns in Zimbabwe that include Harare, Bulawayo, Gweru, Maswingo, Mutare, Kwekwe and Chinhoyi. A sample of 56 respondents consisting of top managers, middle managers and technical staff for the three organizations was then drawn using a simple probability random sampling method. A structured questionnaire was employed in collection of primary cross-section data. As have been previously mentioned, the participants who

\footnotetext{
1 The supply chain process is from production supplier, wholesalers, retailers and consumers
} 
included general managers, middle managers and technical staff were interviewed. Before the main interview and submission of questionnaires, a pilot study was undertaken to ascertain the efficacy of the questions. Modifications were made to the questions wherever necessary to increase clarity of the sample. In the course of January 2014 to March 2015 , in addition to interviews, a standard questionnaire was physically delivered to the 56 respondents. We applied a test method, implying that the hypothesis advanced in the study can be supported or refuted based on primary data collected through the structured questionnaire. The statistical package used for analysis of collected data for the fast moving consumer retail sector was SPSS version 21. By the way of justifying the use of aforementioned methods of data collection and analysis, the use of a simple probability sampling method to select the sample was chosen in order to give respondents equal chance of being included in the sample and to avoid bias. For data analysis the test method was chosen in that we consider hypothesis testing to be an important approach that should ascertain the results and thereby increase our confidence in the findings of the study.

Hypothesis Testing: The hypothesis to be tested is the Null Hypothesis $\left(\mathrm{H}_{0}\right)$ : electronic procurement does not exist in the fast moving consumer goods retail sector in Zimbabwe. $\mathrm{H}_{0}: \boldsymbol{\beta}=\mathbf{0}$ Alternative Hypothesis $\left(\mathrm{H}_{1}\right)$ : electronic procurement exists in the fast moving consumer goods retail sector in Zimbabwe. $\mathrm{H}_{1}: \boldsymbol{\beta} \neq \mathbf{0}$ Let: $\mathrm{N}$ be the sample size $(\mathrm{N}$ $=35) ; P$ is the proportion of shops using electronic procurement extensively. In our case, $P=0.2 ; P \sim N(P, p q / N)$. Step 1 $-H_{0}: \pi>0.5 ; H_{1}: \pi<0.5$ Step 2 -We carry out a one tailed test at $95 \%$ level of confidence( $5 \%$ level of significance) and reject $H_{0}$ if $Z$ cal, > -1.65 , Los $(a)=0.5-0.05=0.45 ; C v=-1.65$; Step 3. Decision rule: reject $H_{0}$ if $Z c a l .>-1.65 ; Z c a l=$ $0.2-0.5 / \sqrt{ }(0.5 \times 0.5 / 35)=-3.55$; Hypothesis is -3.55 meaning to say e-procurement is used in the fast moving consumer goods retail sector and is being used to a lesser extent.The results showed that e-procurement is scant in Zimbabwe's retail industries. The results also indicate that e-procurement was widely used in B2B transactions and none at all in B2C and B2G sectors. Adoption of e-procurement though insignificant was at its peak in the period 2010 up to 2012. The study also showed the importance of e-procurement, its inhibitors and ways to improve e-procurement adoption. However, the results should be interpreted with caution, in that interview bias, among other things, could have an effect on the results

\section{Discussion}

The results indicate little application of e-procurement in Zimbabwe's retail sector. It stands to reason, therefore, that an adoption of e-procurement by firms in the retail sector should lower the administrative ordering cost and thereby improving on profit margins for the firms in the retail industry. On the other hand, the main inhibitors to e-procurement adoption include: Low level of awareness of e-procurement capabilities, fast moving goods retail sector lack sufficient knowledge and skills about the technology, lack of cooperation from suppliers as this calls for mutual commitment from supplier and the retailer. The retail chains do not have internal information technology skills. They lack advice and internal support to sustain e-procurement operations, high cost of e-procurement technology equipment and implementations and security concerns. There was low capacity utilisation for all three types of e-procurement (intra-organisation, business to business and business to customer) in the fast moving consumer goods. Of these three, businesses to customer were the least utilised.

Factors identified as being important for successful adoption of e-procurement include: Knowledge about eprocurement capabilities and how it can benefit businesses-procurement strategy backed at Board level, Staged implementation and retailers should consider investing in formal training programs to equip staff with requisite eprocurement technological skills. Considerations should be given to attaching information technology staff to firms that have fully integrated e-procurement in other countries to learn and experience what is required in creating and managing e-procurement operations. The government could be lobbied to give tax relief for training related to information technology. This would also encourage companies to invest in training workers on how to fully use common package such as MS Word, MS Excel and other e-procurement applications. Trade association such as the Zimbabwe National Chamber of Commerce and the Retail Association of Zimbabwe should make a great concerted effort to promote use of electronic procurement highlighting its capabilities and benefits to all the businesses. Talkers, seminars and exhibitors can be organised regularly to promote use of the electronic procurement technology at various levels in both layman and professional levels. The government should consider using electronic procurement mechanisms or using the internet to deliver services.

To this end, government could invest in creating a vibrant website from where line ministries and departments could be accessed. This move will raise overall awareness and acceptance of the internet as a business tool. The government should consider introducing as an examined subject in schools. This could contribute to raising general awareness of e-procurement among ordinary people as e-procurement is a sub heading of e-commerce. Government 
should consider rewarding those fast moving consumer retail chains taking significant steps towards e-procurement adoption. Such rewards could be in the form of tax breaks, for example fast moving consumer retail chains should consider incorporating e-procurement in hybrid arrangements that is operating the traditional bricks and mortar or physical retail chain and the online retail chain concurrently. However, there is need to guard against structural channel and strategic risk. The Paradigm shifts from companies and individuals customers that view internet as a social tool rather than a business tool.

\section{Conclusion}

The following conclusions are drawn from the foregoing research: There is generally slow growth of e-procurement among retail chains in Zimbabwe. The degree of organisational readiness for use of e-procurement in daily operations of most fast consumer goods retail shops is very low. There was generally superficial awareness among retails in the fast moving consumer goods sector of capabilities of e-procurement technologies. The study revealed that the main benefits of e-procurement include: low administrative ordering cost, speed of information and transaction processing, flexibility to respond to new opportunities, centralisation of data in order to improve audit and analysis, provision of better status monitoring and tracking of applications, improvement in ordering administration and inventory replenishment and logistic. E-procurement also increases transparency in works and services and improves better interaction between supplier, wholesaler, retailer and consumers and citizens through online systems. It is recommended that an adoption of electronic procurement will greatly improve and lower administrative ordering cost and thereby improving profits in the retail sector. Further research would focus on the adoption of e-procurement by the suppliers and wholesalers in Zimbabwe and other developing economies.

\section{References}

Bacel Maddaha, and Mohamad Y. Jaber (2008). Economic order quantity for items with imperfect quantity Rivisited, International Journal of Production, 112(2), 808-815

Batenburg, R. (2007). E-procurement adoption by European firms: A quantitative analysis. Journal of purchasing and supply management, 13, 182-192.

Bidgoli, H. (2013). MIS. Course Technology, Cengage Learning.

Brevis, T., and Vrba, M. (2014). Contemporary Management Principles. Juta and Company Ltd: Cape Town.

Croom, S., \& Johnson, R. (2003). E- Service: Enhancing internal customer service through e-procurement, International Journal of Service Industrial Management. Vol. 14(5) pp. 539-555.

De Boer, L. Harink, J., \& Heijboer, G. (2002). A conceptual model for assessing the impact of electronic procurement. European Journal of Purchasing and Supply Management, vol. 8(1), pp 25-33

Essig, M. \& Arnold, U. (2006). Electronic Procurement in Supply Chain Management: An information economics-based analysis of electronic markets. Journal of supply chain management, vol. 37(3), 43-49.

Grandon, E. E. \& Pearson, J. M. (2004). Electronic Commerce adoption: an empirical study of small and medium US businesses, Information and Management, 42: 197-216.

Jafar Rezaeia, and Negin Salimi (2012). Economic order quantity and Purchasing price for items with imperfect quality when inspection shifts from buyer to supplier, International Journal of production Economics, 139, 11-18

Laryea, S., \& Ibem, O. E. (2014). Patterns of Technological Innovation in the use of E-Procurement in Construction, Journal of information Technology in Construction, Vol 19 (2014), 104-125

Lenung, R., \& Law, R. (2013). Evaluation of Hotel Information Technologies and EDI Adoption: the perspective of Hotel IT managers in Hong Kong, 54(1) 25-37.

Leopoldo Eduardo Carderas-Barrona, Kun-Jen Chung, Gerardo Trevino-Garza (2014). Celebrating a Century of the economic order quantity model in honor of Ford Whitman Harries, International Journal of production Economics, 155, 1-7

Liang-Yuh Ouyanga, Chih-Te Yang, Ya-Lan Chan, Leopoldo Eduardo Cardenas-Barron (2013). A comprehensive extension of the optimal replenishment decisions under two levels of trade credit6 policy depending on the order quantity, Applied Mathematics and Computation224, 268-277

McManus, S. A. (2002). Understanding the incremental nature of e- procurement implementation at the state and local levels, Journal of Public Procurement. Vol. 2(1). Pp. 5-28.

Mehmood Khana, Mohamad Y. Jaber, and Mourice Bonney (2011). An Economic order quantity (EOQ) for items with imperfect quantity and inspection error, International Journal of Production Economics, 133(1), 113-118

Nussbaum, B. (2003). Ubuntu and Business Reflections and Questions, World Business Academy, Perspective, Vol. 17 (3), 1-15

Pattnaik, M (2013). Optimization in an instantaneous economic order quantity (EOQ) model incorporated with promotional effort cost, variable ordering cost and units lost due to deterioration, Uncertain Supply Chain Management, 1,57-66

Posiopoulos, A; Siskou, O.; Prezerakas, P.; Moisoglon, I.; Theodorou, M. \& Kaitelidou, D. (2013). Implementation of e-procurement 
System in health sector in Greece: Altitudes of Potential Users and Implementations for Hospital Management. International Journal of Health Research and Innovation, vol. 1(1), 15-23.

Pycraft, M., Singh, H., Phihlela, K., Slack, N., Chambers. S., and Johnston, R. (2013). Operations Management. Global and Southern African Perspectives. Pearson Education: South Africa.

Rajkumar, T. M. (2001). E - Procurement: Business and technical issues. Information Systems Management, Fall,Vol. 18(4), 52-60.

Sheng-China, Leopoldo Eduardo Cardenas ${ }^{b}$, Jinn-Tsair (2014). Retailer's economic order quantity when the supplier offers conditionally permissible delay in payment link to order quantity. International Journal of production economics, 115,284-291

Subramanian, C., \& Shaw, M.J., (2002). A study of the value and impact of B2B E -Commerce: The case of web-based procurement, International Journal of Electronic Commerce. Vol. 6(4) pp 19-40.

Teo, T. S. H., Lin, S., Lai, K. H. (2009). Adopters and non-adopters of e-procumbent in Singapore: An empirical study. Journal homepage: www.elsevier.com/locate/omega, pp. 972-987 Accessed 30Sept 2014.

Yung-Fu Huang. (2007). Economic order quantity under conditionally permissible delay in payments, European Journal of Operational Research, 176, 911-924 